\title{
Risk of venous thromboembolism associated with Janus kinase inhibitors for rheumatoid arthritis: case presentation and literature review
}

\author{
Shunsuke Mori ${ }^{1} \mathbb{D} \cdot$ Fumihiko Ogata $^{2}$ D $\cdot$ Ryusuke Tsunoda $^{2} \mathbb{D}$
}

Received: 8 June 2021 / Revised: 1 September 2021 / Accepted: 2 September 2021 / Published online: 23 September 2021

(c) The Author(s) 2021

\begin{abstract}
Janus kinase (JAK) inhibitors have been developed as disease-modifying antirheumatic drugs. Despite the positive therapeutic impacts of JAK inhibitors, concerns have been raised regarding the risk of venous thromboembolism (VTE), such as deep vein thrombosis (DVT) and pulmonary embolism (PE). A recent post hoc safety analysis of placebo-controlled trials of JAK inhibitors in rheumatoid arthritis (RA) reported an imbalance in the incidence of VTE for a 4-mg daily dose of baricitinib versus placebo. In a recent postmarketing surveillance trial for RA, a significantly higher incidence of PE was reported in treatment with tofacitinib (10 mg twice daily) compared with tofacitinib $5 \mathrm{mg}$ or tumor necrosis factor inhibitors. We also experienced a case of massive PE occurring 3 months after starting baricitinib (4 mg once daily) for multiple biologicresistant RA. Nevertheless, the evidence to support the role of JAK inhibitors in VTE risk remains insufficient. There are a number of predisposing conditions and risk factors for VTE. In addition to the known risk factors that can provoke VTE, advanced age, obesity, diabetes mellitus, hypertension, hyperlipidemia, and smoking can also contribute to its development. Greater VTE risk is noted in patients with chronic inflammatory conditions, particularly RA patients with uncontrolled disease activity and any comorbidity. Prior to the initiation of JAK inhibitors, clinicians should consider both the number and strength of VTE risk factors for each patient. In addition, clinicians should advise patients to seek prompt medical help if they develop clinical signs and symptoms that suggest VTE/PE.

\section{Key Points}

- Patients with rheumatoid arthritis (RA) are at increased risk of venous thromboembolism (VTE), especially those with uncontrolled, high disease activity and those with comorbidities.

- In addition to the well-known risk factors that provoke VTE events, advanced age and cardiovascular risk factors, such as obesity, diabetes mellitus, hypertension, hyperlipidemia, and smoking, should be considered risk factors for VTE.

- Although a signal of VTE/pulmonary embolism (PE) risk with JAK inhibitors has been noted in RA patients who are already at high risk, the evidence is currently insufficient to support the increased risk of VTE during RA treatment with JAK inhibitors.

- If there are no suitable alternatives, clinicians should prescribe JAK inhibitors with caution, considering both the strength of individual risk factors and the cumulative weight of all risk factors for each patient.
\end{abstract}

Keywords Baricitinib · Deep vein thrombosis · Janus kinase inhibitors · Pulmonary embolism · Rheumatoid arthritis · Tofacitinib

Shunsuke Mori

mori.shunsuke.ra@mail.hosp.go.jp

Fumihiko Ogata

fumihiko.ogata@hotmail.co.jp

Ryusuke Tsunoda

rtsunoda@kumamoto-med.jrc.or.jp
1 Department of Rheumatology, Clinical Research Center for Rheumatic Diseases, National Hospital Organization Kumamoto Saishun Medical Center, 2659 Suya, Kohshi Kumamoto 861-1196, Japan

2 Divsion of Cardiology, Japanese Red Cross Kumamoto Hospital, Kumamoto, Japan 


\section{Introduction}

The Janus kinase (JAK)/signal transducer and activator of transcription (STAT) pathway is one of the major cascades that transfers extracellular cytokine signals from cell surface receptors to the nucleus. There are four isoforms in the JAK family, namely, JAK1, JAK2, JAK3, and TYK2, which act in pairs either as homodimers or as heterodimers to activate STAT proteins. Different cytokine receptor families utilize specific pairs of JAK isoforms for signal transduction [1,2].

Over the last decade, JAK inhibitors, small molecules that target the JAK-STAT signaling pathway, have been developed as targeted synthetic disease-modifying antirheumatic drugs (tsDMARDs) for immune-mediated inflammatory diseases (IMIDs) such as rheumatoid arthritis (RA) [3-5]. Biological DMARDs (bDMARDs), protein molecules that target specific cytokines and cytokine receptors in the inflammatory cascade, have several limitations, including the need for parenteral administration and the development of anti-drug antibodies due to inherent immunogenicity [6]. In the context of these limitations, JAK inhibitors have significant advantages over bDMARDs. In addition, recent randomized clinical trials of JAK inhibitors for RA demonstrated equivalent or even superior efficacy to adalimumab, a tumor necrosis factor (TNF) inhibitor [7-10]. Using realworld registries, we showed that tofacitinib, a first-generation JAK inhibitor, can induce greater improvements during the first 12-month treatment in bDMARD-naïve RA patients compared with tocilizumab, an anti-interleukin-6 receptor antibody [11, 12]. Despite these positive therapeutic impacts of JAK inhibitors, concerns have been raised regarding the risk of venous thromboembolism (VTE), such as deep vein thrombosis (DVT) and pulmonary embolism (PE). In addition, previous meta-analyses indicated a higher background risk of VTE among patients with RA or other IMIDs compared with the general population $[13,14]$.

The aim of this review is to provide the latest update regarding the risk of VTE events associated with JAK inhibitors in RA patients, which can guide therapeutic decisions based on safety considerations. We also share our recent experience with a case of massive PE occurring in the treatment of multiple biologic-resistant RA with a JAK inhibitor, baricitinib, with the intention to discuss the risk management of VTE events.

\section{Case presentation: massive PE during baricitinib therapy for RA}

In April 2010, a 46-year-old female was diagnosed with seropositive RA. The disease activity was moderate. The patient started methotrexate (MTX) monotherapy, but it failed to control the disease activity. Next, the patient attempted four different biological therapies sequentially, starting with etanercept plus MTX, then proceeding to infliximab plus MTX, tocilizumab plus MTX, and abatacept monotherapy, but every therapy failed and the disease activity became high. In March 2020, high-throughput leukocytapheresis (LCAP), which is an alternative therapeutic option for the management of RA with super-resistance to DMARD therapies [15], was initiated. After five LCAP procedures at 1-week intervals, the patient started baricitinib, a JAK1/ JAK2 inhibitor, $4 \mathrm{mg}$ once daily with oral prednisolone. Eight weeks later, the patient achieved low disease activity. Twelve weeks after starting baricitinib therapy, dyspnea and chest pain suddenly appeared on lifting heavy objects. The patient had noticed painless swelling of the left leg 1 week prior to this attack. The patient was immediately taken to an emergency hospital by ambulance because of worsening dyspnea.

In the emergency room, the patient was in shock. The respiratory rate was 30 breaths/min and $\mathrm{SpO}_{2}$ was $90 \%$ with reservoir mask oxygen at $7 \mathrm{~L} / \mathrm{min}$. Arterial blood gas analysis showed $\mathrm{PaO}_{2}$ of 77 Torr, $\mathrm{PaCO}_{2}$ of 29 Torr, and $\mathrm{HCO}_{3}-$ of $19.2 \mathrm{mmol} / \mathrm{L}$. Elevated levels of serum D-dimer $(34.6 \mu \mathrm{g} / \mathrm{mL})$ and brain natriuretic peptide (BNP, $30.1 \mathrm{pg} /$ $\mathrm{mL}$ ) were observed. The electrocardiogram indicated right ventricular strain with a heart rate of 126 beats/min. Transthoracic echocardiography showed a dilated right ventricular dimension $(50.5 \mathrm{~mm})$, McConnell sign (defined as right ventricular free wall akinesis with sparing of the apex), and reduced tricuspid annular plane systolic excursion (TAPSE) to $9.3 \mathrm{~mm}$. These results indicate severe right ventricular systolic dysfunction. Contrast-enhanced computed tomography revealed thrombi in both main pulmonary arteries, the left popliteal vein, and the left superficial femoral vein (Figs. 1 and 2). The patient was diagnosed as developing acute massive PE caused by DVT [16-18]. Anti-phospholipid syndrome-related tests and anti-SARS-Cov-2 antibody tests were negative. The body mass index was 34.2 (obese class I), and no other cardiovascular or VTE risk factors were identified.

The patient was intravenously administered $120 \times 10^{4}$ units of tissue-type plasminogen activator (t-PA) as thrombolytic therapy. On admission day 2, the patient recovered from the shock state, and dyspnea was improved. No bleeding was observed. Oral rivaroxaban $30 \mathrm{mg}$ daily (Xa inhibitor) was used as anticoagulation therapy. On admission day 6 , the patient's dyspnea and hypoxia were resolved. Contrast-enhanced computed tomography revealed that the amounts of thrombi had decreased. The findings of right ventricular strain disappeared. On admission day 10, the patient was discharged with oral rivaroxaban. Certolizumab-pegol plus MTX therapy was newly started. Four months later, the patient 
achieved low disease activity, and the emboli disappeared from the pulmonary arteries and the veins of the left lower limb.

The latest postmarketing surveillance data on safety from pharmaceutical companies in Japan reported six cases of DVT $(0.09 \%)$, two cases of PE $(0.03 \%)$, and one case of venous embolism (0.01\%) in RA patients receiving tofacitinib ( $n=6989$, data cutoff May 5, 2020), and 11 cases of severe VTE $(0.3 \%)$ and seven cases of nonsevere VTE $(0.2 \%)$ in RA patients receiving baricitinib $(n=3445$, data cutoff January 1, 2021). In our institution, tofacitinib or baricitinib was used in approximately 200 RA patients and, as mentioned above, one patient developed massive PE 3 months after starting baricitinib $4 \mathrm{mg}$ once daily.

\section{Search strategy}

The literature search for the current review was carried out in line with the recommendations for bibliographic searches for narrative reviews [19]. Using the PubMed platform, the Medline database was searched on April 30, 2020, for English biomedical literature focusing on VTE risk in RA patients receiving and not receiving JAK inhibitors. The identification of eligible articles was initially carried out by screening titles and abstracts, and finally by reading the full text of the publication. The references of the eligible articles were screened to ensure that no important research data relevant to the subject were missed.

To identify English articles relating to the VTE risk associated with JAK inhibitors, we used the terms (venous
Fig. 1 Contrast-enhanced computed tomography reveals prominent emboli in the bilateral main pulmonary arteries (yellow arrowheads)
Fig. 2 Contrast-enhanced computed tomography reveals occlusive intravenous thrombosis in the left popliteal vein and the left superficial femoral vein (yellow arrowheads)
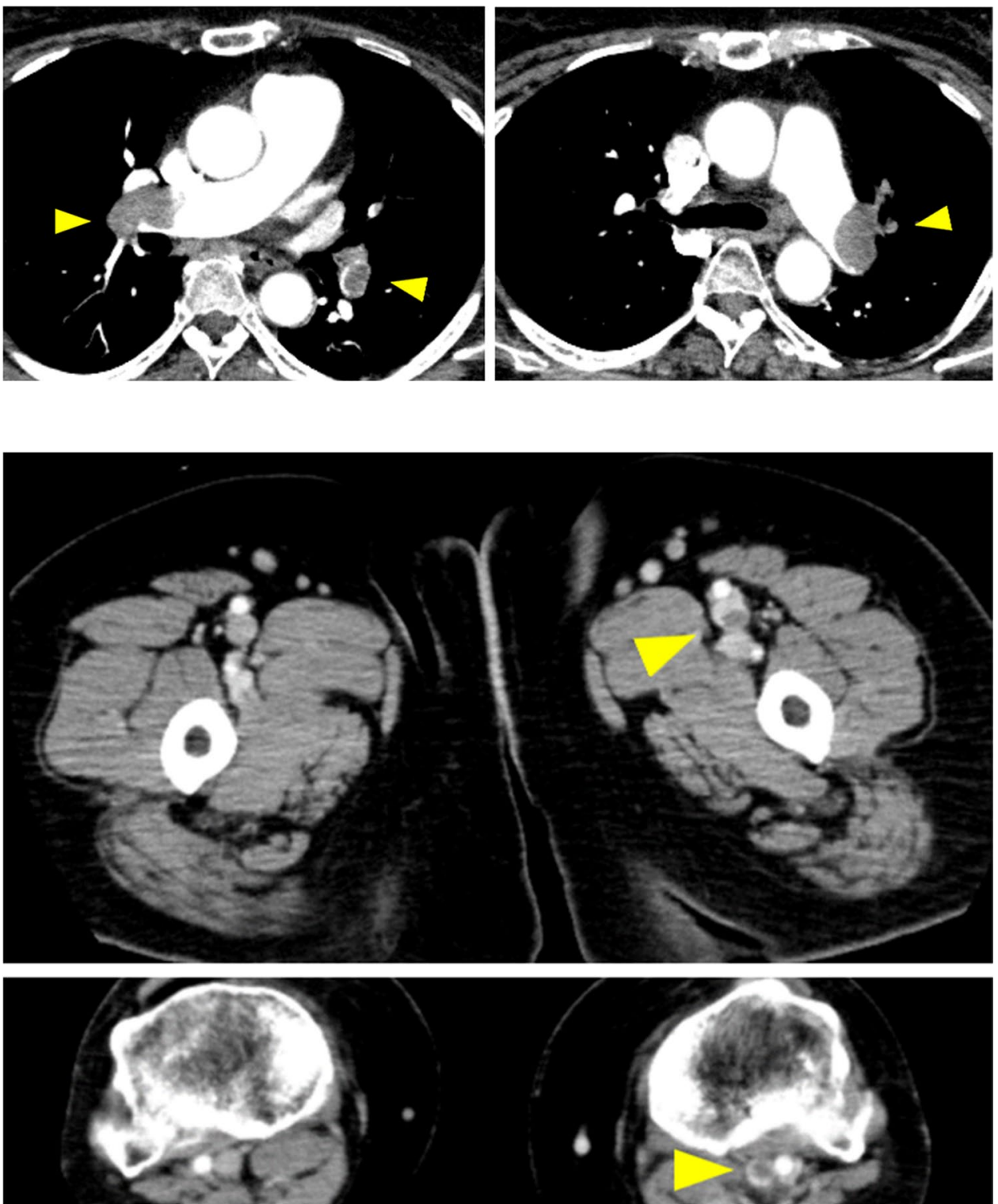
thromboembolism OR venous thromboembolic event OR pulmonary embolism OR deep vein thrombosis) AND (Janus kinase inhibitor OR tofacitinib OR baricitinib OR upadacitinib OR filgotinib OR peficitinib). Through the Medline search, a total of 90 articles were identified. Among them, we found eight post hoc safety analyses, two systematic reviews, and seven systematic reviews/meta-analyses using pooled data from clinical trials and long-term extension (LTE) studies of JAK inhibitors for RA and other IMIDs. In addition, six postmarketing studies using real-world registries of RA and other IMID patients receiving JAK inhibitors were identified (among these 6, one study was also identified and included as a post hoc analysis). We also found three review articles including detailed data on incidence rates of VTEs associated with JAK inhibitors. All of these studies are included in the "VTE events in RA patients receiving JAK inhibitors" section of this review. Individual clinical trials as well as LTE studies were not included in this section because all VTE cases in these studies were incorporated into the abovementioned post hoc analyses and systematic reviews/meta-analyses. We also excluded studies that only focused on patients with non-RA IMIDs.

To identify English articles comparing VTE risk between RA patients and non-RA controls as well as those comparing VTE risks among RA patients based on disease activity, we used the terms (venous thromboembolism OR venous thromboembolic event OR pulmonary embolism OR deep vein thrombosis) AND (rheumatoid arthritis OR autoimmune OR immune-mediated OR inflammatory) AND (incidence OR rate). Through the Medline search, a total of 1608 English articles were identified. Among them, we found 16 eligible articles (15 articles comparing the VTE incidence between RA patients and non-RA controls and one article comparing the VTE incidence among RA patients based on disease activity/severity). These studies are included in the "VTE risks in RA patients" section of this review. Studies focusing on postoperative VTE events or recurrent VTE events were excluded.

Additional articles were also selected based on the prior knowledge of the authors, and the information was synthesized below.

\section{A brief overview of VTE}

\section{Epidemiology of VTE}

VTE is fairly common, and its incidence increases exponentially with age [20,21]. In the majority of cases, VTE manifests as DVT of the legs and pelvis; in 30 to $40 \%$ of patients, it appears as PE. The estimated annual incidence rates (IRs) for VTE, PE (with or without DVT), and DVT alone in Western countries are reported to range from 104 to 183, 29 to 78 , and 45 to 117 per 100,000 person-years, respectively. The recurrence of VTE occurs frequently: approximately $30 \%$ of patients who have a first episode of VTE will experience recurrence within 10 years [22]. A VTE event is a serious medical condition associated with long-term morbidity and increased mortality. In particular, PE is an independent predictor of reduced survival for up to 3 months after the event $[23,24]$. As a result of the westernized lifestyle and aging society in Japan, the number of patients with PE has increased 4.6-fold in the past 15 years, with an estimated annual IR of 12.6 per 100,000 person-years in 2011 [25].

\section{Risk factors for VTE}

In the nineteenth century, the German physician Virchow explained the pathophysiologic mechanisms of VTE by three major determinants, called Virchow's triad, which included hypercoagulability (constituents of blood), endothelial injury (vessel wall), and venous stasis (blood flow) [26]. There are a number of predisposing conditions and risk factors for VTE, which can affect one or more elements of Virchow's triad.

Many episodes of VTE are provoked by a transient or persistent risk factor [27]. Major general surgery, orthopedic surgery (hip or knee replacement), major trauma, fracture (hip or leg), spinal cord injury, and immobilization are categorized as major setting-related (usually transient) risk factors that can provoke VTE. Active cancer is a well-recognized patient-related (usually permanent or progressive) risk factor that can provoke VTE $[18,20,27,28]$. In addition, congestive heart or respiratory failure, infection (such as pneumonia, urinary tract infection, or HIV infection), and acquired thrombophilia (antiphospholipid antibody syndrome, etc.) are considered moderate-risk factors that can provoke VTE. Heart disease such as myocardial infraction and atrial fibrillation (within the previous 3 months) especially increases the risk of PE. In women, pregnancy and puerperium, oral contraceptives, and hormone replacement therapy are recognized as moderately provoking risk factors for VTE [18, 20, 27-29]. A high risk of recurrence has been noted in patients with persistent risk factor(s). A previous episode of VTE should be considered a major risk factor for a new episode [18, 20, 22, 27].

Approximately 40 to $50 \%$ of VTE cases are considered unprovoked or idiopathic, that is, they do not have important provoking factors for VTE (either transient or persistent) $[21,27,30]$. These patients may, however, have minor acquired or inherited predisposing conditions for VTE [25, 27, 30]. Hereditary thrombophilia (antithrombin, protein $\mathrm{C}$, or protein S deficiency, Factor V Leiden or prothrombin G20210A gene mutation, etc.) is considered a minor inherited risk factor. Increasing age is also associated with the risk of VTE [20, 27, 30]. Recently, the contribution of 
non-cancer persistent conditions, including chronic inflammatory diseases and traditional cardiovascular risk factors (such as smoking, obesity, hypertension, diabetes mellitus, and hyperlipidemia) to the pathophysiology of VTE, has been investigated. These conditions may be insufficient to cause VTE when isolated, but they can be factors that predispose an individual to VTE if combined [30].

It is becoming clear that there is a functional interdependence between inflammation and thrombosis, which is mediated by the loss of normal functions of endothelial cells, leading to the dysregulation of coagulation, platelet activation, and leukocyte recruitment in the microvasculature. Chronic inflammation appears to be an important determinant of chronic VTE events [30-32]. An imbalance between pro-thrombotic and anti-thrombotic cytokines may be involved in the pathophysiology of VTE [32].

\section{VTE risks in RA patients}

A number of population-based epidemiological studies showed that the risk of VTE is increased in RA patients compared with the general population. Fifteen studies are summarized in Table 1 [33-47]. RA patients were more likely to experience VTE compared with age- and sexmatched non-RA subjects, even after adjustment for VTE risk factors and comorbidities. In several studies, the VTE risk was stable over follow-up time [36, 39]. In other studies, the VTE risk was highest during the first year, then attenuated with time but remained statistically elevated even 5 years after RA diagnosis [42, 46]. Among hospitalized RA patients, the PE risk was highest during the first year after hospitalization. This risk decreased over time but persisted up to 10 years [41]. These findings suggested that RA should be regarded as a hypercoagulable disorder.

The VTE risk increased with increased disease activity: a twofold increase in VTE risk was observed in RA patients with high disease activity compared with patients in remission (risk ratio [RR] 2.03, 95\% confidence interval [CI] 1.73-2.38) [40]. Poorly controlled RA activity may be associated with the risk of VTE. Using the Optum Clinformatics Data Mart, a United States (US) claims database that includes patients receiving DMARD treatment after the first diagnosis of RA between 2007 and 2017, Liang et al. showed that, after adjustment for multiple risk factors, patients who switched from a bDMARD/tsDMARD to another bDMARD/tsDMARD (bDMARD/tsDMARD switchers) had an increased risk of VTE compared with conventional synthetic DMARD (csDMARD) users (adjusted hazard ratio [HR] 1.36, 95\% CI 1.16-1.58). Compared with first bDMARD/tsDMARD users, the adjusted HR (95\% CI) for VTE was 1.35 (1.15-1.60) for first bDMARD/tsDMARD switchers and 1.48 (1.19-1.85) for second bDMARD/
tsDMARD switchers. These findings suggested that switching bDMARD/tsDMARD may be a proxy for higher disease severity and poorly controlled disease activity in RA [48]. The increased VTE risk observed in RA patients may be attributed, at least in part, to uncontrolled disease activity.

\section{JAK inhibitors currently licensed for RA treatment}

Tofacitinib and baricitinib are first-generation JAK inhibitors, and both have been approved by the US Food and Drug Administration (FDA) and the European Medicines Agency (EMA) [49, 50]. Tofacitinib, a JAK1, JAK2, and JAK3 paninhibitor, was first approved for the treatment of moderately to severely active RA by the FDA in 2012. In 2017, the EMA also recommended the approval of tofacitinib for RA. Currently, the recommended dose of tofacitinib in RA treatment is $5 \mathrm{mg}$ twice daily in most countries. Baricitinib, which has a specificity for JAK 1 and JAK2, is the second approved JAK inhibitor. The use of this drug was approved by the EMA in 2017 at $2 \mathrm{mg}$ or $4 \mathrm{mg}$ once daily for the treatment of moderately to severely active RA. Subsequently, the FDA recommended the approval of a baricitinib 2-mg once-daily dosing regimen for RA treatment in April 2018, but did not recommend the use of $4 \mathrm{mg}$ once daily due to safety concerns related to VTE. In Japan, baricitinib is available in $2 \mathrm{mg}$ and $4 \mathrm{mg}$ once-daily dosing regimens for the treatment of RA.

The next-generation JAK inhibitors upadacitinib and filgotinib were designed with selective affinity to JAK1, which may decrease the risk of unwanted adverse events without compromising clinical efficacy. Upadacitinib was approved by the FDA and EMA for the treatment of moderate to severe RA in 2019. Filgotinib was approved by the EMA, but the FDA did not approve this drug because of concerns relating to its testicular toxicity $[50,51]$.

These four JAK inhibitors are currently available in the treatment of RA in Japan. Peficitinib, a pan JAK inhibitor (a JAK1, JAK2, and JAK 3 inhibitor), is also approved in Japan [50].

\section{VTE events in RA patients receiving JAK inhibitors}

\section{Are JAK inhibitors associated with an increased risk of VTE?}

Numerically higher rates of VTE/PE events were observed in some clinical trials of JAK inhibitors versus placebo, suggesting an increased risk for developing VTE during treatment with JAK inhibitors [5, 52]. Given the rarity of VTE 
Table 1 VTE risks in RA patients versus non-RA controls

\begin{tabular}{|c|c|c|c|c|c|c|}
\hline Study & $\begin{array}{l}\text { Period } \\
\text { (Mean follow-up) } \\
\text { Country }\end{array}$ & Database & $\begin{array}{l}\text { No. of VTEs/total } \\
\text { RA patients }\end{array}$ & $\begin{array}{l}\text { No. of VTEs/total } \\
\text { controls }\end{array}$ & $\begin{array}{l}\text { HRs/RRs/ORs/SIR } \\
(95 \% \mathrm{CI})^{*}\end{array}$ & Comments \\
\hline Bacani et al. [33] & $\begin{array}{l}1995-2008 \\
(5.9 \text { years }) \\
\text { US }\end{array}$ & $\begin{array}{l}\text { Olmsted County, } \\
\text { Minnesota }\end{array}$ & $\begin{array}{l}\text { VTE 19/464 } \\
\text { PE 12/464 } \\
\text { DVT 11/464 }\end{array}$ & $\begin{array}{l}7 / 464 \\
5 / 464 \\
4 / 464\end{array}$ & $\begin{array}{l}\text { HR } 3.6(1.5-8.6) \\
- \\
-\end{array}$ & $\begin{array}{l}\text { Incident RA patients } \\
\text { Matched controls } \\
(1: 1)\end{array}$ \\
\hline \multirow[t]{3}{*}{ Matta et al. [34] } & $\begin{array}{l}\text { 1979-2005 } \\
\text { (NA) }\end{array}$ & \multirow[t]{3}{*}{ NHDS } & $\begin{array}{l}\text { VTE } 110,000 \\
\text { PE } 41,000\end{array}$ & $\begin{array}{l}10,226,000 \\
3,366,000\end{array}$ & $\begin{array}{l}\text { RR } 1.99(1.98- \\
\quad 2.00) \\
\text { RR } 2.25(2.23- \\
2.27)\end{array}$ & \multirow[t]{3}{*}{$\begin{array}{l}\text { Hospitalized patients } \\
\text { without joint } \\
\text { surgery }\end{array}$} \\
\hline & \multirow[t]{2}{*}{ US } & & DVT 79,000 & $7,681,000$ & \multirow[t]{2}{*}{$\begin{array}{l}\text { RR } 1.90(1.89- \\
1.92)\end{array}$} & \\
\hline & & & $/ 4,818,000$ & $/ 891,055,000$ & & \\
\hline Kim et al. [35] & $\begin{array}{l}\text { 2001-2008 } \\
\text { (2.0 years) } \\
\text { US }\end{array}$ & $\begin{array}{l}\text { US insurance } \\
\text { claims database }\end{array}$ & $\begin{array}{l}\text { VTE } 265 / 22,143 \\
\text { PE } 111 / 22,143 \\
\text { DVT } 197 / 22,143\end{array}$ & $\begin{array}{l}448 / 88,572 \\
164 / 88,572 \\
364 / 88,572\end{array}$ & $\begin{array}{l}\text { HR } 1.4(1.1-1.7) \\
\text { HR } 1.9(1.3-2.7) \\
\text { HR } 1.2(0.9-1.5)\end{array}$ & $\begin{array}{l}\text { Matched controls } \\
(1: 4) \\
\text { Adjusted for risk } \\
\text { factors }\end{array}$ \\
\hline Yusuf et al. [36] & $\begin{array}{l}2007-2010 \\
\text { (2.6 years) } \\
\text { US }\end{array}$ & $\begin{array}{c}\text { Truven Health Mar- } \\
\text { ketScan database }\end{array}$ & VTE 909/70,768 & $981 / 198,044$ & $\begin{array}{l}\text { HR } 2.13(1.89- \\
2.40) \text { at } 1 \text { year } \\
\text { HR } 2.03(1.64- \\
2.51) \text { at } 4 \text { years }\end{array}$ & $\begin{array}{l}\text { Adjusted for age, } \\
\text { sex, and risk fac- } \\
\text { tors }\end{array}$ \\
\hline \multirow[t]{3}{*}{ Bleau et al. [37] } & 2003-2011 & $\begin{array}{l}\text { HCUP-NIS data- } \\
\text { base }\end{array}$ & VTE 9/5780 & $5716 / 7,917,453$ & $\begin{array}{l}\text { OR } 1.95(1.01- \\
3.75)\end{array}$ & \multirow[t]{3}{*}{$\begin{array}{l}\text { Pregnant women } \\
\text { Adjusted for age }\end{array}$} \\
\hline & (cross-sectional) & & PE 5/5780 & $1734 / 7,917,453$ & $\begin{array}{l}\text { OR } 3.62(1.50- \\
\quad 8.70)\end{array}$ & \\
\hline & US & & DVT 6/5780 & $4228 / 7,917,453$ & $\begin{array}{l}\text { OR } 1.75(0.78- \\
3.89)\end{array}$ & \\
\hline Yusuf et al. [38] & $\begin{array}{l}2010 \\
\text { (cross-sectional) } \\
\text { US }\end{array}$ & $\begin{array}{l}\text { HCUP-NIS data- } \\
\text { base }\end{array}$ & VTE $2.65 \% / 94,585$ & $2.28 \% / 5,539,809$ & $\begin{array}{l}\text { OR } 1.17(1.13- \\
1.21)\end{array}$ & $\begin{array}{l}\text { Hospitalized patients } \\
\text { Adjusted for age, } \\
\text { sex, race, and risk } \\
\text { factors }\end{array}$ \\
\hline $\begin{array}{l}\text { Holmqvist et al. } \\
\text { [39] }\end{array}$ & $\begin{array}{l}\text { 1997-2010 } \\
\text { (5.8 years, median) } \\
\text { Sweden }\end{array}$ & SRQ Register & VTE $223 / 7904$ & $648 / 37,350$ & $\begin{array}{l}\text { HR } 1.6(1.4-1.9) \\
\text { HR } 1.6(1.1-2.5) \\
\text { within the first } \\
\text { year } \\
\text { HR } 1.9(1.4-2.4) \text { at } \\
\text { 5-9 years }\end{array}$ & $\begin{array}{l}\text { Incident RA } \\
\text { Matched controls } \\
\quad(1: 5) \\
\text { Adjusted for age }\end{array}$ \\
\hline Molander et al. [40] & $\begin{array}{l}\text { 2006-2018 } \\
\text { (1 year) } \\
\text { Sweden }\end{array}$ & SRQ Register & VTE 2241/46,316 & $5301 / 215,843$ & $\begin{array}{l}\text { RR } 1.88(1.65- \\
2.15) \text { within the } \\
\text { first year RR } 2.03 \\
(1.73-2.38) \text { for } \\
\text { high } \\
\text { DAS28 vs. remis- } \\
\text { sion }\end{array}$ & $\begin{array}{l}\text { Matched controls } \\
(1: 5) \\
\text { Adjusted for age, } \\
\text { sex, and calendar } \\
\text { year of visit }\end{array}$ \\
\hline Zoller et al. [41] & $\begin{array}{l}\text { 1964-2008 } \\
\text { (NA) } \\
\text { Sweden }\end{array}$ & MigMed2 database & PE 2500/86,366 & - & $\begin{array}{l}\text { SIR 1.91 (1.83- } \\
1.98) \\
\text { SIR 5.99 (5.59- } \\
\text { 6.41) within the } \\
\text { first year } \\
\text { SIR } 1.18 \\
(1.06-1.31) \text { at } \\
\text { 5-10 years }\end{array}$ & $\begin{array}{l}\text { Hospitalized patients } \\
\text { Adjusted for age, } \\
\text { sex, entry time, } \\
\text { and risk factors }\end{array}$ \\
\hline \multirow[t]{2}{*}{ Choi et al. [42] } & 1986-2010 & \multirow[t]{2}{*}{ THIN } & VTE 176/9589 & $815 / 95,776$ & $\begin{array}{l}\text { RR } 2.14(1.80- \\
\quad 2.54) \\
\text { RR 2.16 (1.68- } \\
\quad 2.79)\end{array}$ & $\begin{array}{l}\text { Incident RA } \\
\text { Matched controls } \\
(1: 10) \\
\text { Adjusted for risk } \\
\text { factors }\end{array}$ \\
\hline & UK & & DVT 110/9589 & $512 / 95,776$ & $\begin{array}{l}\text { RR } 2.16(1.74- \\
2.69)\end{array}$ & $\begin{array}{l}\text { RRs remained high } \\
\text { at }^{\prime} \leq 5 \text { years }^{\dagger}\end{array}$ \\
\hline
\end{tabular}


Table 1 (continued)

\begin{tabular}{|c|c|c|c|c|c|c|}
\hline \multirow[t]{2}{*}{ Study } & $\begin{array}{l}\text { Period } \\
\text { (Mean follow-up) }\end{array}$ & Database & $\begin{array}{l}\text { No. of VTEs/total } \\
\text { RA patients }\end{array}$ & $\begin{array}{l}\text { No. of VTEs/total } \\
\text { controls }\end{array}$ & $\begin{array}{l}\text { HRs/RRs/ORs/SIR } \\
(95 \% \mathrm{CI})^{*}\end{array}$ & Comments \\
\hline & \multicolumn{6}{|l|}{ Country } \\
\hline \multirow[t]{8}{*}{ Ogdie et al. [43] } & 1994-2014 & \multirow[t]{8}{*}{ THIN } & (Without DMARD) & & & \multirow{8}{*}{$\begin{array}{l}\text { Matched controls } \\
\text { Adjusted for age, } \\
\text { sex, and risk fac- } \\
\text { tors }\end{array}$} \\
\hline & \multirow[t]{2}{*}{$\begin{array}{l}\text { (No DMARD: } \\
5.8 \text { years) }\end{array}$} & & VTE $851 / 20,426$ & $30,356 / 1,225,571$ & $\begin{array}{l}\text { HR } 1.29(1.18- \\
1.39)\end{array}$ & \\
\hline & & & PE $186 / 20,426$ & $6066 / 1,225,571$ & $\begin{array}{l}\text { HR } 1.45(1.23- \\
1.72)\end{array}$ & \\
\hline & \multirow[t]{2}{*}{$\begin{array}{l}\text { (With DMARD: } \\
6.2 \text { years) }\end{array}$} & & DVT 702/20,426 & $25,490 / 1,225,571$ & $\begin{array}{l}\text { HR } 1.25(1.15- \\
1.37)\end{array}$ & \\
\hline & & & (With DMARD) & & & \\
\hline & \multirow[t]{3}{*}{ UK } & & VTE $1479 / 31,336$ & $30,356 / 1,225,571$ & $\begin{array}{l}\text { HR } 1.35(1.27- \\
1.44)\end{array}$ & \\
\hline & & & PE 393/31,336 & $6066 / 1,225,571$ & $\begin{array}{l}\text { HR } 1.74(1.55- \\
1.99)\end{array}$ & \\
\hline & & & DVT $1162 / 31,336$ & $25,490 / 1,225,571$ & $\begin{array}{l}\text { HR } 1.29(1.20- \\
1.38)\end{array}$ & \\
\hline \multirow[t]{3}{*}{ Galloway et al. [44] } & 1999-2019 & \multirow[t]{3}{*}{$\begin{array}{l}\text { UK RCGP-RSC } \\
\text { database }\end{array}$} & VTE $845 / 23,410$ & $2020 / 93,640$ & $\begin{array}{l}\text { HR } 1.54(1.40- \\
1.69)\end{array}$ & \multirow{3}{*}{$\begin{array}{l}\text { Matched controls } \\
(1: 4) \\
\text { Adjusted for age, } \\
\text { sex, race, and risk } \\
\text { factors }\end{array}$} \\
\hline & (8.2 years) & & PE $373 / 23,408$ & $916 / 93,639$ & $\begin{array}{l}\text { HR } 1.57(1.36- \\
1.80)\end{array}$ & \\
\hline & UK & & DVT $542 / 23,408$ & $1242 / 93,640$ & $\begin{array}{l}\text { HR } 1.64(1.45- \\
1.84)\end{array}$ & \\
\hline $\begin{array}{l}\text { Ramagopalan et al. } \\
\text { [45] }\end{array}$ & $\begin{array}{l}\text { 1999-2008 } \\
\text { (NA) } \\
\text { UK }\end{array}$ & $\begin{array}{l}\text { English national } \\
\text { HES }\end{array}$ & $6825 / 268,005$ & - & $\begin{array}{l}\text { Rate ratio for VTE } \\
1.75(1.70-1.80)\end{array}$ & $\begin{array}{l}\text { Hospitalized patients } \\
\text { Adjusted for age, } \\
\text { sex, time period, } \\
\text { and residential area }\end{array}$ \\
\hline \multirow[t]{3}{*}{ Li et al. [46] } & 1997-2009 & \multirow[t]{3}{*}{ British Columbia } & VTE $1432 / 39,142$ & $2059 / 78,078$ & $\begin{array}{l}\text { HR } 1.28(1.20- \\
1.36)\end{array}$ & \multirow{3}{*}{$\begin{array}{l}\text { Incident RA } \\
\text { Matched controls } \\
(1: 2) \\
\text { Adjusted for age, } \\
\text { sex, and risk fac- } \\
\text { tors } \\
\text { HRs remained high } \\
\text { within the first } \\
5 \text { years }\end{array}$} \\
\hline & (9.7 years) & & PE 543/39,142 & 791/78,078 & $\begin{array}{l}\text { HR } 1.25(1.13- \\
1.39)\end{array}$ & \\
\hline & Canada & & DVT $1068 / 39,142$ & $1484 / 78,078$ & $\begin{array}{l}\text { HR } 1.30(1.21- \\
\quad 1.40)\end{array}$ & \\
\hline \multirow[t]{3}{*}{ Chung et al. [47] } & 1998-2010 & \multirow[t]{3}{*}{ Taiwan NHIRD } & PE $70 / 29,238$ & $139 / 116,952$ & $\begin{array}{l}\text { HR } 2.07(1.55- \\
2.76)\end{array}$ & $\begin{array}{l}\text { Matched controls } \\
(1: 4)\end{array}$ \\
\hline & (6.6 years) & & DVT $208 / 29,238$ & $255 / 116,952$ & HR $3.36(2.79-$ & Adjusted for age, \\
\hline & Taiwan & & & & 4.03) & $\begin{array}{l}\text { sex, and risk fac- } \\
\text { tors }\end{array}$ \\
\hline
\end{tabular}

VTE events included PE and DVT, occurring both individually and in combination

*The HR, RR, and OR of VTE events in RA patients were calculated compared with those in non-RA patients. Factors used for adjustment are described in the "Comments" column. The SIR was calculated by dividing the observed number of VTE cases in the RA group by the expected number of cases in the reference population with the indirect standardization method. The rate ratio was calculated as the ratio of the observed/ expected numbers in the RA cohort to those in the reference cohort

${ }^{\dagger}$ The time-specific RRs were highest within the first year after RA diagnosis (3.27 [95\% CI 1.78-6.00] for PE and 3.16 [95\% CI 1.95-5.11] for DVT), but persisted at elevated levels at 5 years and more (2.35 [95\% CI 1.59-3.46] for PE and 2.32 [95\% CI 1.64-3.27] for DVT)

${ }^{\ddagger}$ The time-specific HRs were highest during the first year after RA diagnosis (1.60 [95\% CI 1.27-2.00] for VTE, 1.86 [95\% CI 1.21-2.86] for $\mathrm{PE}$, and 1.59 [95\% CI 1.20-2.10] for DVT), but persisted at high levels within the first 5 years (1.28 [95\% CI 1.15-1.42] for VTE, 1.29 [95\% CI $1.09-1.53$ ] for PE, and 1.27 [95\% CI 1.12-1.43] for DVT)

$R A$, rheumatoid arthritis; VTE, venous thromboembolism; $P E$, pulmonary embolism; $D V T$, deep vein thrombosis; $H R$, hazard ratio; $R R$, risk ratio; $O R$, odds ratio; SIR, standardized incidence ratio; DAS28, disease activity score for 28 joints; NHDS, National Hospital Discharge Survey; HCUP-NIS, Health Care Cost and Utilization Project National Impatient Sample; SRQ, Swedish Rheumatology Quality; THIN, The Health Improvement Network; RCGP-RSC, Royal College General Practitioners Research and Surveillance Center; HES, Hospital Episode Statistics; NHIRD, National Health Insurance Research Database; NA, not available 
events, however, it is difficult to identify statistically clear signals for increased VTE risks in individual clinical trials. In addition, the higher background thromboembolic risk in RA patients versus non-RA patients may make it complicated to confirm or exclude a significant difference in risk between JAK inhibitors and placebo [53, 54]. To address this issue, a number of post hoc safety analyses and systematic reviews/meta-analyses of clinical trials and LTE studies as well as postmarketing studies using real-world registries have been conducted.

\section{Post hoc safety analyses of VTE events in clinical trials and LTE studies}

There are eight post hoc safety analyses for clinical trials and LTE studies of four JAK inhibitors, namely, tofacitinib, baricitinib, upadacitinib, and peficitinib, for RA [55-62].

\section{Baricitinib}

In post hoc safety analyses using integrated data pooled from phase I, II, and III clinical trials (8 studies) as well as one LTE study of baricitinib for RA, no VTE events occurred in 1070 placebo-treated patients, but six VTE events were observed in 997 patients treated with a 4-mg daily dose of baricitinib during the 24-week placebo-controlled period. All VTE patients had conventional VTE risk factors. During extended observations, the IRs were similar between baricitinib 2 and $4 \mathrm{mg}$, with IRs of 0.5 per 100 patient-years versus 0.6 per 100 patient-years. In all patients receiving baricitinib (All-Bari-RA, a total of 3492), the IR was 0.5 per 100 patient-years and stable over time [55, 56]. The IR of VTE events increased with older age in the All-Bari-RA group [63]. In post hoc safety analyses that were limited to Japanese or East Asian patients in the ALL-Bari-RA group (5 phase II and III trials and 1 LTE study), the IRs of DVT were 0.3 to 0.5 per 100 patient-years and there were no $\mathrm{PE}$ events $[57,58]$.

\section{Tofacitinib}

In a post hoc safety analysis of pooled data from phase I, II, III, and IIIb/IV clinical trials as well as LTE studies of tofacitinib for RA (a total of 7964 tofacitinib-treated patients), the IRs of thromboembolic events (per 100 patient-years) in patients receiving tofacitinib $5 \mathrm{mg}$ and $10 \mathrm{mg}$ twice daily were 0.17 and 0.15 for DVT, 0.12 and 0.13 for PE, and 0.24 and 0.26 for VTE, respectively. The IRs in patients with and without cardiovascular risk factors were 0.24 and 0.11 for DVT, 0.25 and 0.06 for PE, and 0.43 and 0.15 for VTE, respectively. The IRs in patients with and without VTE risk factors were 0.21 and 0.07 for DVT, 0.16 and 0.04 for PE, and 0.35 and 0.10 for VTE, respectively. Thus, the IRs of
VTE events in the tofacitinib development program were similar between 5 and $10 \mathrm{mg}$ twice-daily doses, and higher in patients with cardiovascular or VTE risk factors versus those without. Similar findings were obtained in patients with psoriatic arthritis and those with psoriasis [59]. Similar IRs were obtained from another integrated safety analysis of data from phase I, II, III, and IIIb/IV clinical trials (19 studies), and LTE studies (2 studies) of tofacitinib for RA (a total of 7061 tofacitinib-treated patients) [60].

\section{Upadacitinib}

In a post hoc safety analysis using integrated data pooled from phase III clinical trials (5 studies) of upadacitinib for RA (a total of 3834 upadacitinib-treated patients), the IRs of VTE events (per 100 patient-years) in patients receiving upadacitinib $15 \mathrm{mg}$ and $30 \mathrm{mg}$ once daily were 0.6 and 0.3 , respectively. The IRs were similar across treatment groups (0.4 for placebo, 0.5 for MTX, and 1.1 for adalimumab) [61].

\section{Peficitinib}

In a post hoc pooled safety analysis using integrated data from phase IIb and III clinical trials (3 trials) as well as one LTE study of peficitinib for RA (a total of 1052 peficitinib-treated patients), the IR of VTE events was 0.1 per 100 patient-years for peficitinib-treated patients, and no VTE events were observed in the placebo group. No dosedependency was observed [62].

\section{Systematic reviews/meta-analyses of clinical trials and LTE studies}

Seven meta-analyses using data extracted from clinical trials of JAK inhibitors for RA and other IMIDs were identified in the literature. These studies are summarized in Table 2 [64-70]. The meta-analyses for RA showed that there was no significant difference in the risk of VTE events between patients receiving JAK inhibitors and those receiving placebo. During the limited placebo-controlled periods, no dose-dependent impact on the risk of VTE events was observed in tofacitinib ( $5 \mathrm{mg}$ vs. $10 \mathrm{mg}$ twice daily), baricitinib ( $2 \mathrm{mg}$ vs. $4 \mathrm{mg}$ once daily), or upadacitinib (15 mg vs. $30 \mathrm{mg}$ once daily) [64, 65]. The meta-analyses for IMIDs (including RA) showed that VTE risk was unlikely to substantially increase in patients receiving JAK inhibitor during the limited placebo-controlled periods [66-69]. In a stratified and meta-regression analysis, there was no interaction by dose of JAK inhibitors, indication for treatment, or length of follow-up [68]. In an indirect meta-analysis, the risk of VTE events in tofacitinib-treated patients was lower than in baricitinib-treated patients (OR 0.09, 95\% CI 0.02-0.51), suggesting the superior safety profile of tofacitinib to 
baricitinib [69]. No increased risk was found for PE during treatment with JAK inhibitors for IMIDs including RA [70].

\section{VTE events in postmarketing studies using real-world registries}

There are six postmarketing studies using real-world registries of RA and other IMID patients receiving JAK inhibitors $[59,71-75]$. In a disproportionality analysis of data extracted from the postmarketing FDA's Adverse Event Reporting System (FAERS) from March 2017, no evidence for increased reporting rates for DVT or PE was identified across three FDA-approved JAK inhibitors, tofacitinib, tofacitinib extended-release, and ruxolitinib (reporting odds ratios [RORs] and empirical Bayesian geometric means $<1$ ). However, this study showed that pulmonary arterial thrombosis (PT) may be a potential safety issue for tofacitinib, with an ROR of 2.46 (95\% CI 1.55-3.91) [71].

In descriptive and disproportionality analysis of data extracted in April 2019 from the World Health Organization global database (VigiBase) of individual case safety reports for tofacitinib and baricitinib, patients with DVT or PT/PE were older and more often received prothrombotic medications or antithrombotic treatment, suggesting a preexisting thromboembolic risk/event. In Europe, tofacitinib was associated with elevated reporting for DVT (ROR 2.37, 95\% CI 1.23-4.56) and PT/PE (ROR 2.38, 95\% CI 1.45-3.89). Similar increased reporting for DVT and PT/PE was observed in baricitinib-treated patients (ROR 3.47, 95\% CI 2.18-5.52; and ROR 3.44, 95\% CI 2.43-4.88, respectively). In the USA, tofacitinib was associated with an increased reporting rate of PT (ROR 2.05, 95\% CI 1.45-2.90), but no evidence for elevated reporting was identified for DVT or PE $(\mathrm{ROR}<1)$. DVT or PT/PE cases were not reported in baricitinib-treated patients in the US [72].

In an observational cohort study using claims data from two databases, the crude IRs of VTE (per 100 patient-years) for tofacitinib and TNF inhibitors in RA patients were 0.60 and 0.34 in the Truven MarketScan database (2012-2016, 1910 tofacitinib initiators and 32,164 TNF-inhibitor initiators) and 1.12 and 0.92 in the Medicare Claims database (2012-2015, 995 tofacitinib initiators and 16,091 TNFinhibitor initiators), respectively. The PS-adjusted HRs had no statistically significant differences in VTE risk between tofacitinib and TNF inhibitors in either database, with a pooled HR of 1.33 (95\% CI 0.78-2.24) [73]. The IRs of VTE in these databases were higher compared with those in the tofacitinib development program for RA [59]. With the accumulation of additional data from more recent years in these two databases (the MarketScan database [2012-2018] and the Medicare database [2012-2017]) and the inclusion of a third database (the Optum Clinformatics database [2012-2019]), an updated analysis was conducted by the same research group. The crude IRs of VTE (per 100 patient-years) for tofacitinib and TNF inhibitors were 0.42 and 0.35 in MarketScan, 1.18 and 0.83 in Medicare, and 0.19 and 0.34 in Optum, respectively. PS-adjusted HRs showed no statistically significant differences in VTE risk between tofacitinib and TNF inhibitors in any database, with a pooled HR of 1.13 (95\% CI 0.77-1.65) [74].

In a post-approval comparative safety study using the US Corrona RA Registry, an ongoing longitudinal clinical registry from November 2012 through July 2018 (1999 tofacitinib initiators and 8358 TNF-inhibitor initiators), the IRs of VTE per 100 patient-years were 0.29 in tofacitinib initiators ( $5 \mathrm{mg}$ twice daily in most cases) and 0.33 in bDMARD initiators, which were numerically similar between tofacitinib initiators and bDMARD initiators [75]. The IRs of VTE were numerically similar between RA patients in the Corrona Registry and those in the tofacitinib development program [59].

A recent ongoing postmarketing safety surveillance trial, ORAL Surveillance (Study A39212233), which is evaluating the safety of tofacitinib versus TNF inhibitors among RA patients aged $\geq 50$ years and with at least one cardiovascular risk factor, raised concerns of a higher incidence of PE and all-cause mortality in patients treated with tofacitinib $10 \mathrm{mg}$ twice daily compared with tofacitinib $5 \mathrm{mg}$ twice daily or TNF inhibitors. In an ad hoc safety analysis (data cutoff February 2019), the IRs per 100 person-years in the treatments with tofacitinib $5 \mathrm{mg}$ twice daily, tofacitinib $10 \mathrm{mg}$ twice daily, and TNF inhibitors were $0.30,0.38$, and 0.18 for DVT and $0.27,0.54$, and 0.09 for PE, respectively. Compared with TNF inhibitors, the HRs (95\% CI) for DVT and PE were $1.66(0.60-4.57)$ and $2.99(0.81-11.06)$ with tofacitinib $5 \mathrm{mg}$ twice daily and $2.13(0.80-5.69)$ and $5.96(1.75-20.33)$ with tofacitinib $10 \mathrm{mg}$ twice daily, respectively. The IRs of thromboembolic events observed in the tofacitinib development program for RA patients with cardiovascular or VTE risk factors were broadly consistent with those observed in the ORAL Surveillance trial. However, the IR of PE was significantly greater in patients receiving tofacitinib $10 \mathrm{mg}$ twice daily in the ORAL Surveillance trial [59].

\section{Unanswered questions}

As summarized above, in the systematic reviews and metaanalyses of data from clinical trials, the evidence was not sufficient to support the increased risk of VTE events during RA treatment with JAK inhibitors. These studies are limited by the small number of events reported and the limited overall exposure. In addition, patients with substantial cardiovascular risk factors and comorbidities are often excluded from such clinical trials. The postmarketing ORAL Surveillance analysis reported a significantly higher incidence of PE and all-cause mortality in RA patients treated with tofacitinib 
Table 2 Meta-analyses of VTE risk in clinical trials of JAK inhibitors for RA and other IMIDs

\begin{tabular}{|c|c|c|c|c|c|c|c|c|}
\hline \multirow[t]{2}{*}{ Study } & \multirow[t]{2}{*}{ JAK inhibitors } & \multirow[t]{2}{*}{ No. of study ${ }^{\dagger}$} & \multicolumn{2}{|c|}{ JAK inhibitors $^{\dagger}$} & \multicolumn{2}{|c|}{ Placebo $^{\dagger}$} & \multirow{2}{*}{$\begin{array}{l}\text { ORs/RRs/RDs } \\
(95 \% \mathrm{CI}) *\end{array}$} & \multirow[t]{2}{*}{ Others } \\
\hline & & & Events & Total & Events & Total & & \\
\hline \multirow[t]{7}{*}{ Xie et al. [64] } & Overall & 25 for RA & 12 & 2193 PYs & 3 & 982 PYs & OR $1.16(0.48-2.81)$ & $\begin{array}{l}\text { (Dose dependency: } \\
\text { OR) }\end{array}$ \\
\hline & Tofacitinib & 9 & 1 & 809 PYs & 2 & 205 PYs & OR $0.17(0.03-1.05)$ & $\begin{array}{l}5 \text { vs. } 10 \mathrm{mg}: 0.81 \\
(0.22-3.03)\end{array}$ \\
\hline & Baricitinib & 6 & 7 & 693 PYs & 1 & 561 PYs & OR $2.33(0.62-8.75)$ & $\begin{array}{l}2 \text { vs. } 4 \mathrm{mg}: 0.23 \\
(0.02-2.17)\end{array}$ \\
\hline & Upadacitinib & 4 & 4 & 285 PYs & 0 & 115 PYs & $\begin{array}{l}\text { OR } 1.77(0.20- \\
\quad 16.00)\end{array}$ & $\begin{array}{l}15 \text { vs. } 30 \mathrm{mg}: 4.36 \\
\quad(0.47-40)\end{array}$ \\
\hline & Filgotinib & 1 & 0 & 178 PYs & 0 & 42 PYs & - & - \\
\hline & Peficitinib & 3 & 0 & 179 PYs & 0 & 42 PYs & - & - \\
\hline & Decernotinib & 2 & 0 & 49 PYs & 0 & 17 PYs & - & - \\
\hline Xie et al. [65] & Tofacitinib & 12 for RA & 1 & 881 PYs & 2 & 263 PYs & OR $0.06(0.00-0.95)$ & $\begin{array}{l}\text { (Dose dependency: } \\
\text { OR) } \\
10 \text { vs. } 5 \mathrm{mg}: 1.47 \\
(0.25-8.50)\end{array}$ \\
\hline \multirow[t]{5}{*}{ Yates et al. [66] } & Overall & $\begin{array}{l}18 \text { for IMIDs (11 } \\
\text { for RA) }\end{array}$ & $12(10)$ & $\begin{array}{l}1950 \text { PYs } \\
\quad(1601 P Y s)\end{array}$ & $4(3)$ & 709 PYs (625 PYs) & $\begin{array}{l}\text { RR } 0.68(0.36-1.29) \\
\text { for IMIDs }\end{array}$ & $\begin{array}{l}\text { RR } 0.44(0.28-0.70) \\
\text { for PE } \\
\text { RR } 0.59(0.31-1.15) \\
\text { for DVT }\end{array}$ \\
\hline & Tofacitinib & $7(3)$ & $2(1)$ & $1069(758)$ & $3(2)$ & $122(77)$ & - & - \\
\hline & Baricitinib & $2(2)$ & $3(3)$ & $234(234)$ & 0 & 107 (107) & - & - \\
\hline & Upadacitinib & $6(5)$ & $6(6)$ & $475(450)$ & $1(1)$ & $378(352)$ & - & - \\
\hline & Filgotinib & $3(1)$ & $1(0)$ & $172(159)$ & 0 & $102(89)$ & - & - \\
\hline \multirow[t]{5}{*}{ Olivera et al. [67] } & Overall & $\begin{array}{l}10 \text { for IMIDs ( } 6 \text { for } \\
\text { RA) }\end{array}$ & $12(11)$ & $\mathbf{n}=3740(2566)$ & $3(0)$ & $\mathbf{n}=1403(997)$ & $\begin{array}{l}\text { RR } 0.90(0.32-2.54) \\
\text { for IMIDs }\end{array}$ & $\begin{array}{l}\text { RR } 1.70(0.48-6.01) \\
\quad \text { for RA }\end{array}$ \\
\hline & Tofacitinib & $4(2)$ & $3(3)$ & 2060 (1009) & $3(0)$ & $536(254)$ & - & - \\
\hline & Baricitinib & $1(1)$ & $2(2)$ & $374(374)$ & 0 & $210(210)$ & - & - \\
\hline & Upadacitinib & $2(2)$ & $5(5)$ & $883(883)$ & 0 & $385(385)$ & - & - \\
\hline & Filgotinib & $3(1)$ & $2(1)$ & $423(300)$ & 0 & $272(148)$ & - & - \\
\hline \multirow[t]{8}{*}{ Bilal et al. [68] } & Overall & $\begin{array}{l}25 \text { for IMIDs (14 } \\
\quad \text { for RA) }\end{array}$ & $50(26)$ & $\mathbf{n}=8933(6254)$ & $27(4)$ & $\mathbf{n}=3612(2490)$ & $\begin{array}{l}\text { OR } 0.91(0.57-1.47) \\
\text { for IMIDs }\end{array}$ & $\begin{array}{l}\text { OR } 1.11(0.50-2.44) \\
\quad \text { for RA }\end{array}$ \\
\hline & Tofacitinib & $7(4)$ & $5(4)$ & $3690(2301)$ & $5(2)$ & $908(521)$ & $\begin{array}{l}\text { OR } 0.27(0.08-0.89) \\
\text { for IMIDs }\end{array}$ & $\begin{array}{l}\text { OR } 0.54(0.15-1.96) \\
\text { for } 10 \mathrm{mg} \text { BID } \\
\text { OR } 0.49(0.15-1.55) \\
\text { for } 5 \mathrm{mg} \mathrm{BID}\end{array}$ \\
\hline & Baricitinib & $5(3)$ & $9(7)$ & $1292(862)$ & $1(1)$ & 487 (348) & $\begin{array}{l}\text { OR } 1.12(0.27-4.69) \\
\text { for IMIDs }\end{array}$ & $\begin{array}{l}\text { OR } 2.69 \\
\quad(0.42-17.21) \text { for } \\
4 \mathrm{mg} \text { QD } \\
\text { OR 3.05 } \\
\quad(0.12-75.43) \text { for } \\
2 \mathrm{mg} \text { QD }\end{array}$ \\
\hline & Upadacitinib & $4(4)$ & $12(12)$ & 2277 (2277) & $1(1)$ & $1256(1256)$ & $\begin{array}{l}\text { OR } 2.25(0.55-9.25) \\
\text { for IMIDs }\end{array}$ & $\begin{array}{l}\text { OR2.64 }(0.27-25.45) \\
\text { for } 30 \mathrm{mg} \text { QD } \\
\text { OR2.91 }(0.69-12.21) \\
\text { for } 15 \mathrm{mg} \text { QD }\end{array}$ \\
\hline & Filgotinib & $2(1)$ & $2(1)$ & $358(300)$ & 0 & $206(148)$ & $\begin{array}{l}\text { OR } 2.13(0.22- \\
20.64) \text { for IMIDs }\end{array}$ & - \\
\hline & Ruxolitinib & $4(0)$ & $19(0)$ & $591(0)$ & $20(0)$ & $482(0)$ & $\begin{array}{l}\text { OR } 0.85(0.31-2.29) \\
\quad \text { for IMIDs }\end{array}$ & - \\
\hline & Decernotinib & $2(2)$ & $2(2)$ & $514(514)$ & 0 & 217 (217) & $\begin{array}{l}\text { OR } 1.07(0.18-6.43) \\
\text { for IMIDs }\end{array}$ & - \\
\hline & Abrocitinib & $1(0)$ & $1(0)$ & $211(0)$ & 0 & $56(0)$ & $\begin{array}{l}\text { OR } 0.81(0.03- \\
20.03) \text { for IMIDs }\end{array}$ & - \\
\hline $\begin{array}{l}\text { Gimenez Poderos } \\
\text { et al. [69] }\end{array}$ & Tofacitinib & $\begin{array}{l}5 \text { for IMIDs (2 for } \\
\text { RA) }\end{array}$ & - & - & - & - & $\begin{array}{l}\text { OR } 0.29(0.10-0.84) \\
\quad \text { for all doses }\end{array}$ & $\begin{array}{l}\text { OR } 1.19(0.12-11.69) \\
\text { for } 3 \mathrm{mg} \mathrm{BID} \\
\text { OR } 0.18(0.02-1.60) \\
\text { for } 5 \mathrm{mg} \mathrm{BID} \\
\text { OR } 0.19(0.04-0.91) \\
\text { for } 10 \mathrm{mg} \text { BID } \\
\text { OR } 0.32(0.01-8.05) \\
\text { for } 15 \mathrm{mg} \text { BID }\end{array}$ \\
\hline
\end{tabular}


Table 2 (continued)

\begin{tabular}{|c|c|c|c|c|c|c|c|c|}
\hline \multirow[t]{2}{*}{ Study } & \multirow[t]{2}{*}{ JAK inhibitors } & \multirow[t]{2}{*}{ No. of study ${ }^{\dagger}$} & \multicolumn{2}{|c|}{ JAK inhibitors $^{\dagger}$} & \multicolumn{2}{|c|}{ Placebo $^{\dagger}$} & \multirow{2}{*}{$\begin{array}{l}\text { ORs/RRs/RDs } \\
(95 \% \mathrm{CI}) *\end{array}$} & \multirow[t]{2}{*}{ Others } \\
\hline & & & Events & Total & Events & Total & & \\
\hline & Baricitinib & $\begin{array}{l}5 \text { for IMIDs (4 for } \\
\text { RA) }\end{array}$ & - & - & - & - & $\begin{array}{l}\text { OR } 3.39 \\
\text { (0.82-14.04) for } \\
\text { all doses }\end{array}$ & $\begin{array}{l}\text { OR } 3.05(0.12-75.43) \\
\text { for } 2 \mathrm{mg} \text { QD } \\
\text { OR } 3.64(0.59-22.46) \\
\text { for } 4 \mathrm{mg} \text { QD } \\
\text { OR } 3.00(0.12-76.49) \\
\text { for } 7 \mathrm{mg} \mathrm{QD}\end{array}$ \\
\hline \multirow[t]{8}{*}{ Khoo et al. [70] } & Overall & $\begin{array}{l}27 \text { for IMIDs ( } 21 \\
\text { for RA) }\end{array}$ & $12(10)$ & $n=8363(7270)$ & $3(3)$ & $n=3314(2858)$ & $\begin{array}{l}\text { RD } 0.000(-0.002- \\
\quad 0.003)\end{array}$ & - \\
\hline & Tofacitinib & $10(8)$ & $3(3)$ & 4178 (3705) & $2(2)$ & 1251 (1095) & $\begin{array}{l}0.000(-0.003- \\
0.003)\end{array}$ & - \\
\hline & Baricitinib & $7(6)$ & $3(2)$ & $2176(1967)$ & $1(1)$ & 1354 (1249) & $\begin{array}{l}0.000(-0.003- \\
0.004)\end{array}$ & - \\
\hline & Upadacitinib & $2(2)$ & $2(2)$ & 469 (469) & 0 & $106(106)$ & $\begin{array}{l}0.005(-0.015- \\
0.024)\end{array}$ & - \\
\hline & Filgotinib & $2(0)$ & $1(0)$ & $123(0)$ & 0 & $124(0)$ & $\begin{array}{l}0.005(-0.020- \\
0.030)\end{array}$ & - \\
\hline & Peficitinib & $1(1)$ & 0 & $238(238)$ & 0 & $51(51)$ & $\begin{array}{l}0.000(-0.027- \\
0.027)\end{array}$ & - \\
\hline & Decernotinib & $2(1)$ & $1(1)$ & $451(163)$ & 0 & $112(41)$ & $\begin{array}{l}0.001(-0.016- \\
0.019)\end{array}$ & - \\
\hline & Fostamatinib & $3(3)$ & $2(2)$ & 728 (728) & 0 & $316(316)$ & $\begin{array}{l}0.003(-0.006- \\
0.012)\end{array}$ & - \\
\hline
\end{tabular}

VTE events included PE and DVT, occurring both individually and in combination

*The ORs, RRs, and RDs of VTE events in patients receiving JAK inhibitors were calculated compared with those receiving placebo

${ }^{\dagger}$ The numbers in parentheses represent study numbers, PYs, event numbers, or patient numbers for RA patients

Fnly PE events were included

$J A K$, Janus kinase; $R A$, rheumatoid arthritis; IMID, immune-mediated inflammatory disease; VTE, venous thromboembolism; PE, pulmonary embolism; $D V T$, deep vein thrombosis; $P Y s$, person-years; $O R$, odds ratio; $R R$, risk ratio; $R D$, risk difference; $95 \% C I, 95 \%$ confidence interval; $B I D$, twice a day; $Q D$, once a day

$10 \mathrm{mg}$ twice daily. The FDA and EMA recommend that JAK inhibitors be avoided in patients with known VTE risk factors if alternative therapies are available. The package inserts for all approved JAK inhibitor products contain a box warning regarding the increased VTE risk [50].

Nevertheless, it is not entirely clear whether JAK inhibitors have a direct causal role in thromboembolic events or whether this risk simply represents a higher background thromboembolic risk in patients with RA (attributable to RA itself or its comorbidities) [53, 54]. There is a close relationship between the inflammatory activity of a given cytokine and its role in thrombus formation. In animal models, anti-inflammatory treatment is effective for thrombus resolution and the reduction of vessel wall damage $[32,76]$. The JAK-STAT pathway can transmit signals from a variety of cytokines that have pro- or anti-thrombotic activity as well as pro- or anti-inflammatory activity. If blocking the JAK-STAT pathway results in a reduction of a particular cytokine's inflammatory activity, it should induce the inhibition of prothrombotic activity. The real-world clinical data indicated that this is not entirely the case, however [77]. Whether the thromboembolic complications may be a class effect or a different JAK inhibitor may carry distinct VTE risks, possibly related to the specificity of JAK inhibitor action, remains unanswered [54, 77].

\section{Risk management of VTE in RA patients}

When making a therapeutic decision of whether or not to start a JAK inhibitor for RA patients who are refractory to biological DMARDs, clinicians should carefully consider the following risk factors that predispose them to VTE events.

1. RA disease activity. RA is an independent risk factor for VTE. Disease activity is significantly associated with an increased risk of VTE. Our PE case presented in this review had received four biological DMARDs over 10 years, but the disease activity was poorly controlled. After the commencement of baricitinib, the patient achieved low disease activity, but DVT/PE occurred.

2. Comorbidities. Approximately $40 \%$ of RA patients suffer from some type of extra-articular manifestations during the course of their disease. The respiratory system is one of the most frequent targets of extra-articular manifesta- 
tions [78]. In addition, the number of elderly RA patients with cardiovascular risk factors is increasing. Older patients are at increased risk of VTE because of multiple comorbid conditions and pharmaceutical changes related to drug metabolism and excretion [63]. Chronic kidney disease (CKD) and non-alcoholic fatty liver disease (NAFLD) have also been seen more commonly in this patient population $[79,80]$. The presence of nonalcoholic steatohepatitis (NASH), a progressive form of NAFLD, is reported to downregulate the cytochrome P450 (CYP) 3A4 enzyme in the liver [81]. Tofacitinib is primarily metabolized through the CYP3A4 enzyme and excreted via the kidneys. Baricitinib is metabolized not via the CYP system but via the kidneys [50]. Thus, the presence of CKD and NAFLD/NASH can contribute to the increased risk of VTE associated with these JAK inhibitors. Dose adjustment is recommended in patients with renal impairment and/or NAFLD/NASH.

3. VTE and cardiovascular risk factors. As listed in the "Risk factors for VTE" section, numerous transient and persistent risk factors that can provoke VTE have been reported. Additional risk factors to be considered when prescribing JAK inhibitors include increased age and traditional cardiovascular risk factors such as obesity, diabetes, hypertension, hyperlipidemia, and smoking. It is important to recognize that the predictive values of these factors are not equal. Clinicians should consider both the strength of individual risk factors and the cumulative weight of all risk factors for each patient $[18,20]$.

4. Patient education. When a patient complains of warmth or redness in the leg, dyspnea, chest pain, and/or syncope during treatment with JAK inhibitors, clinicians should suspect the development of VTE/PE and initiate a rapid diagnostic workup. Prior to the initiation of JAK inhibitors, we should inform each patient of the number and strength of his/her risk factors for VTE, and advise them to seek prompt medical help if they develop clinical signs and symptoms that suggest VTE/PE.

\section{Limitations}

We performed a literature search to comprehensively collect and analyze all sources relating to the risk of VTE events in RA patients receiving or not receiving JAK kinase inhibitors. We obtained relevant data from a variety of articles published in rheumatology, pharmacology, cardiology, hematology, and epidemiology journals, which contributed to the reduction of a selection bias. In addition, we included detailed information on the massive and acute PE case that we experienced during baricitinib treatment for multiple biologic-resistant RA, which provides critical information regarding the risk management of VTE events in RA patients who are scheduled to receive JAK inhibitor therapy.

There are several limitations to this study. First, we undertook literature searches solely through the Medline database, and, therefore, we might have missed some relevant studies. Second, we mainly focused on VTE events associated with the five JAK inhibitors approved for RA, namely, tofacitinib, baricitinib, upadacitinib, filgotinib, and peficitinib. Several new JAK inhibitors have been developed for IMIDs, but detailed data on VTE risk of individual new-generation JAK inhibitors were not available in the literature. Third, our review focused on the VTE risk in RA patients, and did not cover patients with other IMIDs such as psoriasis, inflammatory bowel diseases, and other inflammatory rheumatic diseases. We cannot entirely exclude the possibility that there may be a difference in VTE risk between patients with RA and those with non-RA IMIDs.

\section{Conclusions}

To date, the evidence is limited and insufficient to support the idea that there is an increased risk of VTE during RA treatment with JAK inhibitors. In addition, the exact mechanisms of how JAK inhibitors might increase the risk of VTE remain to be clarified. A signal of VTE/PE risk with JAK inhibitors has been noted in RA patients who are already at high risk, however. Clinicians should follow the regulatory recommendations to avoid the use of JAK inhibitors in patients with cardiovascular and VTE risk factors if alternative therapies are available. If suitable alternatives are not available, clinicians should prescribe JAK inhibitors with caution, taking the number and strength of VTE risk factors for each RA patient into careful consideration.

\section{Declarations}

Patient consent Written informed consent for publication was obtained.

Publishing agency We did not use the services of external publishing agents.

Conflict of interest The authors have declared that no conflicts of interest exist.

Disclaimer No part of this manuscript has been copied or published elsewhere.

Open Access This article is licensed under a Creative Commons Attribution 4.0 International License, which permits use, sharing, adaptation, distribution and reproduction in any medium or format, as long as you give appropriate credit to the original author(s) and the source, provide a link to the Creative Commons licence, and indicate if changes 
were made. The images or other third party material in this article are included in the article's Creative Commons licence, unless indicated otherwise in a credit line to the material. If material is not included in the article's Creative Commons licence and your intended use is not permitted by statutory regulation or exceeds the permitted use, you will need to obtain permission directly from the copyright holder. To view a copy of this licence, visit http://creativecommons.org/licenses/by/4.0/.

\section{References}

1. Gadina M, Johnson C, Schwartz D et al (2018) Translational and clinical advances in JAK-STAT biology: the present and future of jakinibs. J Leukoc Biol 104:499-514

2. Fragoulis GE, McInnes IB, Siebert S (2019) JAK-inhibitors. New players in the field of immune-mediated diseases, beyond rheumatoid arthritis. Rheumatology (Oxford) 58:i43-i54

3. Schwartz DM, Kanno Y, Villarino A, Ward M, Gadina M, O'Shea JJ (2017) JAK inhibition as a therapeutic strategy for immune and inflammatory diseases. Nat Rev Drug Discov 16:843-862

4. Bechman K, Yates M, Galloway JB (2019) The new entries in the therapeutic armamentarium: the small molecule JAK inhibitors. Pharmacol Res 147:104392

5. Kerschbaumer A, Smolen JS, Nash P et al (2020) Points to consider for the treatment of immune-mediated inflammatory diseases with Janus kinase inhibitors: a systematic literature research. RMD Open 6:e001374

6. Strand V, Goncalves J, Isaacs JD (2021) Immunogenicity of biologic agents in rheumatology. Nat Rev Rheumatol 17:81-97

7. van Vollenhoven RF, Fleischmann R, Cohen S et al (2012) Tofacitinib or adalimumab versus placebo in rheumatoid arthritis. $\mathrm{N}$ Engl J Med 367:508-519

8. Fleischmann R, Mysler E, Hall S et al (2017) Efficacy and safety of tofacitinib monotherapy, tofacitinib with methotrexate, and adalimumab with methotrexate in patients with rheumatoid arthritis (ORAL Strategy): a phase 3b/4, double-blind, head-to-head, randomised controlled trial. Lancet 390:457-468

9. Taylor PC, Keystone EC, van der Heijde D et al (2017) Baricitinib versus placebo or adalimumab in rheumatoid arthritis. N Engl J Med 376:652-662

10. Fleischmann R, Pangan AL, Song IH et al (2019) Upadacitinib versus placebo or adalimumab in patients with rheumatoid arthritis and an inadequate response to methotrexate: results of a phase III, double-blind, randomized controlled trial. Arthritis Rheumatol 71:1788-1800

11. Mori S, Urata Y, Yoshitama T, Ueki Y (2021) Tofacitinib versus tocilizumab in the treatment of biological-naive or previous biological-failure patients with methotrexate-refractory active rheumatoid arthritis. RMD Open 7:e01601

12. Mori S, Yoshitama T, Ueki Y (2018) Tofacitinib therapy for rheumatoid arthritis: a direct comparison study between biologic-naïve and experienced patients. Intern Med 57:663-670

13. Ungprasert P, Srivali N, Spanuchart I, Thongprayoon C, Knight EL (2014) Risk of venous thromboembolism in patients with rheumatoid arthritis: a systematic review and meta-analysis. Clin Rheumatol 33:297-304

14. Lee JJ, Pope JE (2014) A meta-analysis of the risk of venous thromboembolism in inflammatory rheumatic diseases. Arthritis Res Ther 16:435

15. Mori S (2020) Leukocytapheresis for rheumatoid arthritis cases that are super-resistant to any class of biological drugs and tofacitinib. Transfus Apher Sci 59:102920

16. Jaff MR, McMurtry MS, Archer SL et al (2011) Management of massive and submassive pulmonary embolism, iliofemoral deep vein thrombosis, and chronic thromboembolic pulmonary hypertension: a scientific statement from the American Heart Association. Circulation 123:1788-1830

17. Goldhaber SZ, Bounameaux H (2012) Pulmonary embolism and deep vein thrombosis. Lancet 379:1835-1846

18. Konstantinides SV, Meyer G, Becattini C et al (2020) 2019 ESC Guidelines for the diagnosis and management of acute pulmonary embolism developed in collaboration with the European Respiratory Society (ERS). Eur Heart J 41:543-603

19. Gasparyan AY, Ayvazyan L, Blackmore H, Kitas GD (2011) Writing a narrative biomedical review: considerations for authors, peer reviewers, and editors. Rheumatol Int 31:1409-1417

20. Anderson FA Jr, Spencer FA (2003) Risk factors for venous thromboembolism. Circulation 107:19-16

21. Naess IA, Christiansen SC, Romundstad P, Cannegieter SC, Rosendaal FR, Hammerstrom J (2007) Incidence and mortality of venous thrombosis: a population-based study. J Thromb Haemost 5:692-699

22. Heit JA (2015) Epidemiology of venous thromboembolism. Nat Rev Cardiol 12:464-474

23. Goldhaber SZ (2012) Venous thromboembolism: epidemiology and magnitude of the problem. Best Pract Res Clin Haematol 25:235-242

24. Heit JA, Spencer FA, White RH (2016) The epidemiology of venous thromboembolism. J Thromb Thrombolysis 41:3-14

25. Nakamura M, Yamada N, Ito M (2015) Current management of venous thromboembolism in Japan: current epidemiology and advances in anticoagulant therapy. J Cardiol 66:451-459

26. Blann AD, Lip GY (2001) Virchow's triad revisited: the importance of soluble coagulation factors, the endothelium, and platelets. Thromb Res 101:321-327

27. Kearon C, Ageno W, Cannegieter SC et al (2016) Categorization of patients as having provoked or unprovoked venous thromboembolism: guidance from the SSC of ISTH. J Thromb Haemost 14:1480-1483

28. Rogers MA, Levine DA, Blumberg N, Flanders SA, Chopra V, Langa KM (2012) Triggers of hospitalization for venous thromboembolism. Circulation 125:2092-2099

29. Sorensen HT, Horvath-Puho E, Lash TL et al (2011) Heart disease may be a risk factor for pulmonary embolism without peripheral deep venous thrombosis. Circulation 124:1435-1441

30. Riva N, Donadini MP, Ageno W (2015) Epidemiology and pathophysiology of venous thromboembolism: similarities with atherothrombosis and the role of inflammation. Thromb Haemost 113:1176-1183

31. Jackson SP, Darbousset R, Schoenwaelder SM (2019) Thromboinflammation: challenges of therapeutically targeting coagulation and other host defense mechanisms. Blood 133:906-918

32. Najem MY, Couturaud F, Lemarie CA (2020) Cytokine and chemokine regulation of venous thromboembolism. J Thromb Haemost 18:1009-1019

33. Bacani AK, Gabriel SE, Crowson CS, Heit JA, Matteson EL (2012) Noncardiac vascular disease in rheumatoid arthritis: increase in venous thromboembolic events? Arthritis Rheum 64:53-61

34. Matta F, Singala R, Yaekoub AY, Najjar R, Stein PD (2009) Risk of venous thromboembolism with rheumatoid arthritis. Thromb Haemost 101:134-138

35. Kim SC, Schneeweiss S, Liu J, Solomon DH (2013) Risk of venous thromboembolism in patients with rheumatoid arthritis. Arthritis Care Res (Hoboken) 65:1600-1607

36. Yusuf HR, Hooper WC, Grosse SD, Parker CS, Boulet SL, Ortel TL (2015) Risk of venous thromboembolism occurrence among adults with selected autoimmune diseases: a study among a U.S. cohort of commercial insurance enrollees. Thromb Res 135:50-57

37. Bleau N, Patenaude V, Abenhaim HA (2016) Risk of venous thromboembolic events in pregnant patients with autoimmune 
diseases: a population-based study. Clin Appl Thromb Hemost 22:285-291

38. Yusuf HR, Hooper WC, Beckman MG, Zhang QC, Tsai J, Ortel TL (2014) Risk of venous thromboembolism among hospitalizations of adults with selected autoimmune diseases. J Thromb Thrombolysis 38:306-313

39. Holmqvist ME, Neovius M, Eriksson J et al (2012) Risk of venous thromboembolism in patients with rheumatoid arthritis and association with disease duration and hospitalization. JAMA 308:1350-1356

40. Molander V, Bower H, Frisell T, Askling J (2021) Risk of venous thromboembolism in rheumatoid arthritis, and its association with disease activity: a nationwide cohort study from Sweden. Ann Rheum Dis 80:169-175

41. Zoller B, Li X, Sundquist J, Sundquist K (2012) Risk of pulmonary embolism in patients with autoimmune disorders: a nationwide follow-up study from Sweden. Lancet 379:244-249

42. Choi HK, Rho YH, Zhu Y, Cea-Soriano L, Avina-Zubieta JA, Zhang Y (2013) The risk of pulmonary embolism and deep vein thrombosis in rheumatoid arthritis: a UK population-based outpatient cohort study. Ann Rheum Dis 72:1182-1187

43. Ogdie A, Kay McGill N, Shin DB et al (2018) Risk of venous thromboembolism in patients with psoriatic arthritis, psoriasis and rheumatoid arthritis: a general population-based cohort study. Eur Heart J 39:3608-3614

44. Galloway J, Barrett K, Irving P et al (2020) Risk of venous thromboembolism in immune-mediated inflammatory diseases: a UK matched cohort study. RMD Open 6:e001392

45. Ramagopalan SV, Wotton CJ, Handel AE, Yeates D, Goldacre MJ (2011) Risk of venous thromboembolism in people admitted to hospital with selected immune-mediated diseases: record-linkage study. BMC Med 9:1

46. Li L, Lu N, Avina-Galindo AM et al (2021) The risk and trend of pulmonary embolism and deep vein thrombosis in rheumatoid arthritis: a general population-based study. Rheumatology (Oxford) 60:188-195

47. Chung WS, Peng CL, Lin CL et al (2014) Rheumatoid arthritis increases the risk of deep vein thrombosis and pulmonary thromboembolism: a nationwide cohort study. Ann Rheum Dis 73:1774-1780

48. Liang H, Danwada R, Guo D et al (2019) Incidence of inpatient venous thromboembolism in treated patients with rheumatoid arthritis and the association with switching biologic or targeted synthetic disease modifying antirheumatic drugs (DMARDs) in the real-world setting. RMD Open 5:e001013

49. Taylor PC (2019) Clinical efficacy of launched JAK inhibitors in rheumatoid arthritis. Rheumatology (Oxford) 58:i17-i26

50. Nash P, Kerschbaumer A, Dorner T et al (2021) Points to consider for the treatment of immune-mediated inflammatory diseases with Janus kinase inhibitors: a consensus statement. Ann Rheum Dis 80:71-87

51. Westhovens R (2019) Clinical efficacy of new JAK inhibitors under development. Just more of the same? Rheumatology (Oxford) 58:i27-i33

52. Sepriano A, Kerschbaumer A, Smolen JS et al (2020) Safety of synthetic and biological DMARDs: a systematic literature review informing the 2019 update of the EULAR recommendations for the management of rheumatoid arthritis. Ann Rheum Dis 79:760-770

53. Scott IC, Hider SL, Scott DL (2018) Thromboembolism with Janus kinase (JAK) inhibitors for rheumatoid arthritis: how real is the risk? Drug Saf 41:645-653

54. Dorner T (2020) Lessons from tofacitinib in patients with cardiovascular risk factors: increased pulmonary embolism or isolated (thrombotic) pulmonary occlusion rates? Ann Rheum Dis 79:1389-1392
55. Taylor PC, Weinblatt ME, Burmester GR et al (2019) Cardiovascular safety during treatment with baricitinib in rheumatoid arthritis. Arthritis Rheumatol 71:1042-1055

56. Smolen JS, Genovese MC, Takeuchi T et al (2019) Safety profile of baricitinib in patients with active rheumatoid arthritis with over 2 years median time in treatment. J Rheumatol 46:7-18

57. Chen YC, Yoo DH, Lee CK et al (2020) Safety of baricitinib in East Asian patients with moderate-to-severe active rheumatoid arthritis: an integrated analysis from clinical trials. Int J Rheum Dis 23:65-73

58. Harigai M, Takeuchi T, Smolen JS et al (2020) Safety profile of baricitinib in Japanese patients with active rheumatoid arthritis with over 1.6 years median time in treatment: an integrated analysis of Phases 2 and 3 trials. Mod Rheumatol 30:36-43

59. Mease P, Charles-Schoeman C, Cohen S et al (2020) Incidence of venous and arterial thromboembolic events reported in the tofacitinib rheumatoid arthritis, psoriasis and psoriatic arthritis development programmes and from real-world data. Ann Rheum Dis 79:1400-1413

60. Cohen SB, Tanaka Y, Mariette X et al (2020) Long-term safety of tofacitinib up to 9.5 years: a comprehensive integrated analysis of the rheumatoid arthritis clinical development programme. RMD Open 6:e001395

61. Cohen SB, van Vollenhoven RF, Winthrop KL et al (2020) Safety profile of upadacitinib in rheumatoid arthritis: integrated analysis from the SELECT phase III clinical programme. Ann Rheum Dis 80:304-311

62. Takeuchi T, Tanaka Y, Tanaka S et al (2021) Safety and effectiveness of peficitinib (ASP015K) in patients with rheumatoid arthritis: final results (32 months of mean peficitinib treatment) from a long-term, open-label extension study in Japan, Korea, and Taiwan. Rheumatol Ther 8:425-442

63. Rajasimhan S, Pamuk O, Katz JD (2020) Safety of Janus kinase inhibitors in older patients: a focus on the thromboembolic risk. Drugs Aging 37:551-558

64. Xie W, Huang Y, Xiao S, Sun X, Fan Y, Zhang Z (2019) Impact of Janus kinase inhibitors on risk of cardiovascular events in patients with rheumatoid arthritis: systematic review and meta-analysis of randomised controlled trials. Ann Rheum Dis 78:1048-1054

65. Xie W, Xiao S, Huang Y, Sun X, Zhang Z (2019) Effect of tofacitinib on cardiovascular events and all-cause mortality in patients with immune-mediated inflammatory diseases: a systematic review and meta analysis of randomized controlled trials. Ther Adv Musculoskelet Dis 11:1759720X19895492

66. Yates M, Mootoo A, Adas M et al (2021) Venous thromboembolism risk with JAK inhibitors: a meta-analysis. Arthritis Rheumatol 73:779-788

67. Olivera PA, Lasa JS, Bonovas S, Danese S, Peyrin-Biroulet L (2020) Safety of Janus kinase inhibitors in patients with inflammatory bowel diseases or other immune-mediated diseases: a systematic review and meta-Analysis. Gastroenterology 158:e1512

68. Bilal J, Riaz IB, Naqvi SAA et al (2021) Janus kinase inhibitors and risk of venous thromboembolism: a systematic review and meta-analysis. Mayo Clin Proc 96:1861-1873

69. Gimenez Poderos T, Gallardo Borge S, Vazquez-Ferreiro P (2020) Risk of venous thromboembolism associated with tofacitinib and baricitinib: a systematic review and indirect meta-analysis. Pharmacotherapy 40:1248-1264

70. Khoo JK, Barnes H, Key S, Glaspole IN, Ostor AJ (2020) Pulmonary adverse events of small molecule JAK inhibitors in autoimmune disease: systematic review and meta-analysis. Rheumatology (Oxford) 59:2217-2225

71. Verden A, Dimbil M, Kyle R, Overstreet B, Hoffman KB (2018) Analysis of spontaneous postmarket case reports submitted to the FDA regarding thromboembolic adverse events and JAK inhibitors. Drug Saf 41:357-361 
72. Vallejo-Yague E, Weiler S, Micheroli R, Burden AM (2020) Thromboembolic safety reporting of tofacitinib and baricitinib: an analysis of the WHO VigiBase. Drug Saf 43:881-891

73. Desai RJ, Pawar A, Weinblatt ME, Kim SC (2019) Comparative risk of venous thromboembolism in rheumatoid arthritis patients receiving tofacitinib versus those receiving tumor necrosis factor inhibitors: an observational cohort study. Arthritis Rheumatol 71:892-900

74. Desai RJ, Pawar A, Khosrow-Khavar F, Weinblatt ME, Kim SC (2021) Risk of venous thromboembolism associated with tofacitinib in patients with rheumatoid arthritis: a population-based cohort study. Rheumatology (Oxford) Online ahead of print.

75. Kremer JM, Bingham CO 3rd, Cappelli LC et al (2021) Postapproval comparative safety study of tofacitinib and biological disease-modifying antirheumatic drugs: 5-year results from a United States-based rheumatoid arthritis registry. ACR Open Rheumatol 3:173-184

76. Mosevoll KA, Johansen S, Wendelbo O, Nepstad I, Bruserud O, Reikvam H (2018) Cytokines, adhesion molecules, and matrix metalloproteases as predisposing, diagnostic, and prognostic factors in venous thrombosis. Front Med (Lausanne) 5:147

77. Kotyla PJ, Engelmann M, Giemza-Stoklosa J, Wnuk B, Islam MA (2021) Thromboembolic adverse drug reactions in Janus kinase
(JAK) inhibitors: does the inhibitor specificity play a role? Int $\mathrm{J}$ Mol Sci 22:2449

78. Mori S (2015) Management of rheumatoid arthritis patients with interstitial lung disease: safety of biological antirheumatic drugs and assessment of pulmonary fibrosis. Clin Med Insights Circ Respir Pulm Med 9:41-49

79. Mori S, Yoshitama T, Hirakata N, Ueki Y (2017) Prevalence of and factors associated with renal dysfunction in rheumatoid arthritis patients: a cross-sectional study in community hospitals. Clin Rheumatol 36:2673-2682

80. Mori S, Arima N, Ito M et al (2020) Incidence predictive factors and severity of methotrexate-related liver injury in rheumatoid arthritis: a longitudinal cohort study. Rheumatol Adv Pract 4:rkaa020

81. Cobbina E, Akhlaghi F (2017) Non-alcoholic fatty liver disease (NAFLD) - pathogenesis, classification, and effect on drug metabolizing enzymes and transporters. Drug Metab Rev 49:197-211

Publisher's note Springer Nature remains neutral with regard to jurisdictional claims in published maps and institutional affiliations. 